Author: Roulin, Stéphanie

Source: Twentieth Century Communism, Volume 7, Number 7 , November 2014, pp. 153-173(21)

Publisher: Lawrence and Wishart

DOI: https://doi.org/10.3898/175864314813903999

\section{A martyr factory? Roman Catholic crusade, Protestant missions and anti-communist propaganda against Soviet anti-religious policies, 1929-37}

\section{Stéphanie Roulin}

$\mathbf{R}$ ecent historiography has revealed the significant impact of religion n cold war politics, whether in terms of propaganda, private diplomacy, the foreign policy of the USA or more generally in international relations. ${ }^{1}$ Religious issues were no less significant during the inter-war era, during which period longstanding opposition to secularism and worries about the anti-religious persecutions in the USSR became linked, and declared sides of the same, ominous coin. This era can be seen as a turning point in the history of clashes over religion, which now reached levels that recalled the culture war ('Kulturkampf) of the nineteenth century - but also involved unparalleled violence and unprecedented transnational scope.

This essay paints a panorama of the various European responses to the brutal Soviet policy against religion, and the evolution of militant atheism in Europe, from the onset of the collectivisation of agriculture in the USSR in 1929 until the encyclical letter Divini Redemptoris (1937), in which Pope Pius XI condemned communism as intrinsically wrong'. After 1917, western opposition to Soviet religious policy developed according to different modalities, which ranged from genuine relief and charity actions to anti-communist and anti-socialist lobbying by groups seeking domestic political advantages. Efforts were undertaken to build a united front against communism, most prominently by the Entente internationale anticommuniste (EIA) and the related conservative groups on which this article focuses. ${ }^{2}$ Founded in 1924 in Geneva, the EIA can aptly 
be described as the first transnational, explicitly anti-communist organisation. ${ }^{3}$ Its members called for an all-Christian crusade for the martyrs, and in repeated exhortations sought to induce feelings of guilt towards them, following the example of the EIA president Theodore Aubert:

The worshippers and the cult servants [in Russia] are ferreted out, imprisoned, slaughtered because of their faith. Their martyrdom came at last to the knowledge of the believers of the other countries ... It is a new crusade which begins against the persecutors of Faith. This crusade is necessary in order to relieve the conscience of those who do not accept to be, because of their silence, accomplices of the Bolshevist executioners. ${ }^{4}$

Aiming to attract public attention to the persecutions and to call for a reaction of all believers to defend Christian civilisation, EIA agitation found a wider audience only after the Holy See had publicly denounced Soviet godlessness in early February 1930. Despite sincere concerns for the fate of persecuted Christians within the Soviet empire, the EIA's leadership and most of its European members had no intention of developing charitable actions to help them, but instead drummed out their martyrdom for propaganda purposes. They denounced the 'hand of Moscow' as being behind every action of secularist Europeans, including anti-clerical acts of violence in civil war Spain; and even saw Moscow as being behind the persecutions of the 'Cristeros' by the radical laicist regime - unrelated to communism - of president Plutarco Elías Calles in remote Mexico. ${ }^{5}$

Through a 1933 creation, the international, multidenominational Pro Deo commission (1933-9), the EIA leadership asked Protestant, Catholic and Orthodox Christians to meet together on a regular basis. ${ }^{6}$ That this improbable invitation was taken up is due partly to the strength of anticommunism within conservative groups, and partly to the effectiveness of the all-encompassing reference to the martyr, leading back to the first Christians in the Roman Empire, and a time when Christianity was not yet divided. That it would be truly all-encompassing was, again, not to be taken for granted, given that Protestant tradition rejected sainthood and martyrology. ${ }^{7}$ But improvements in the Protestant-Catholic dialogue in the 1930s, especially in Switzerland where the Pro Deo reunions took place, along with the strength of anti-communism, pulled off the feat. ${ }^{8}$ And it was indeed all-encompassing, as the word martyr came to embrace not only victims of anti-religious policy, but victims of the 1933 famine and - according to EIA and Pro Deo - victims of the Soviet system in general.

Pro Deo selected martyrs to defend - excluding Catholics and Protestants under Nazi rule, as well as German Jews - and failed to achieve its goals because of denominational jealousy, political narrowness and nationalist interests. The longer sequel nevertheless shows that this failure did not in the least taint the currency of the idea of the martyr, which eventually took on a second life during the Cold War and beyond. We shall later return to the continuing life of this 'martyr factory' after the fall of communism: it still persists today in Christian churches and defence movements, though in a context where the persecutors are no longer the same, and the reference to the 'East' has shifted.

\section{Bolshevik anti-religious agitation and policies}

Before and during 1917, religion was barely addressed in the Bolsheviks' message. ${ }^{9}$ The struggle against religion and superstition became a priority only after the October revolution. As soon as the Bolsheviks took power, they entered into conflict with the Orthodox Church, the dominant religion in most Russian areas of the empire. The revolutionary government started a process of violent persecution, aiming at the annihilation of the institution that had been the loyal servant of the tsarist regime. However, recent studies on church-state relationships and on anti-religious policy in the USSR have pointed out that neither the Bolshevik party nor the church and its believers could be considered as a monolith. ${ }^{10}$ Such studies have identified three main phases of persecution before the great shift of 1941 ushered in by wartime patriotism, but insisted that no unified position on atheism or religion ever existed, even among the Bolshevik leadership. ${ }^{11}$

The first of these phases was that of the civil war era, between the 23 January 1918 decree on separation of church and state and the end of 1920. The party central committee led a bloody attack against the 
Orthodox clergy and laity for their real or alleged sympathies with the Whites, and for their resistance to the enforcement of the nationalisation of church property. Highly publicised measures included breaking into places of worship, opening up sacred relics to expose them as fraudulent and confiscating ecclesiastical goods. ${ }^{12}$

During the second phase of persecutions, between 1921 and 1928, the party created multiple state agencies in charge of the political and scientific 'enlightenment', a phrase that implied both the promotion of atheism and the aim of eradicating illiteracy. ${ }^{13}$ But it remained undecided whether the new, class-free society that was wished for was to be non-religious or anti-religious. Inner-party struggle, political opportunism and 'dialectical' flexibility did not help clarify this important nuance, and, until 1928, advocates of a gentle and pragmatic atheist activism prevailed over those in favour of a rapid repression of religion. A 'renovationist', pro-communist schism from the mainstream church was temporarily encouraged and instrumentalised by the regime between 1922 and 1927. This 'Living Church' caused important controversies within ecclesiastical ranks, and had a greater impact than was previously acknowledged in earlier historiography. Even so, it was unable to gain any substantial popular support. ${ }^{14}$ Meanwhile, anti-religious strategies did the atheist cause more harm than good. ${ }^{15}$ Agitation was left to amateurs at the local level, and was far too provocative and simplistic to be effective. The debates with religious personalities organised by atheist leaders such as Anatoly Lunacharsky often turned out to the disadvantage of the atheists. After a first acknowledgement of failure, anti-religious propaganda was intensified in 1925 with the creation by Emelian Yaroslavsky of the League of the Godless. This was responsible for anti-religious agit-prop, especially in rural areas where religious observance was stronger than in urban zones. With the Bezbozhnik (Godless) journal it produced and its assistance from the Komsomol (the youth organisation), the League was perceived abroad as the incarnation of a devilish regime.

The movement was nevertheless a failure, as Yaroslavsky was forced to recognise: only some ten million persons, out of a population of over 130 million, had left the church in the USSR by the end of the $1920 \mathrm{~s} .{ }^{16}$ Orthodoxy was deeply embedded in Russian culture. With 150 to 200 church holidays a year, of which around fifty were days off before the revolution, the church was synonymous with leisure. ${ }^{17}$ Its rites provided the rhythm of social life. According to the Moscow civil status registry, 57.8 per cent of births and 66.7 per cent of deaths were still marked by a religious ritual in 1928 . The rate in the countryside, meanwhile, was over 95 per cent. ${ }^{18}$ Opportunities provided by Soviet legislation and differences within the state apparatus allowed local clergy and parishioners to oppose anti-religious policies, through strategies ranging from passivity and feigned incompetence to violence and terrorism against the militant atheists. ${ }^{19}$ Later, refusal and circumvention gave way to accommodation, a behaviour that did not necessarily implied submission. Even after the hardening of 1928-9, believers were able to use the Soviet laws to their advantage, for example by using the right to petition and gathering funds to reopen the churches. ${ }^{20}$

The third phase started in 1929, when the League undertook a more aggressive bent, symbolised by the changing of its name to League of the Militant Godless, and decided on the final assault against all religions. Restrictive laws on 'religious associations' were enacted in the spring of 1929. These prohibited manifestations of religious faith in public, as well as church propaganda, marking a clear departure from the 1924 constitution, which had allowed both religious and anti-religious propaganda. Children had to be preserved from any religious influence at school and at home, and were encouraged to despise their parents' beliefs. In the autumn of 1929, the closure of places of worship and the persecution of the clergy was generally the first step in the forced collectivisation campaigns in the countryside. Having fallen victim to growing discrimination throughout the 1920s, priests now suffered even more brutal treatment: imprisonment, deportation and even execution. The other Christian denominations, Muslims and religious Jews, who had been granted a relative tolerance until 1928, were also subjected to persecutions. ${ }^{21}$ In 1929 and 1930, clergy and lay Baptists, Lutherans and Roman Catholics were accused of spying on behalf of foreign countries, of terrorism and counter-revolutionary behaviour, and of private trade in religious objects, all of which crimes could lead to several years imprisonment. ${ }^{22}$ This intensification of the persecutions did not pass unnoticed abroad, yet the reactions were not immediate, even in well-informed 
institutions such as the Vatican, which had a vested interest in the religious future of Russia.

\section{Phases and forms of protest abroad}

Because anti-religious policies mainly focused on the Orthodox Church during the 1920s, they aroused only isolated reactions from religious and political circles in Europe. Only in 1929, after the regime had declared war against all religions within the USSR, did protests increase. The first West European mobilisation against these religious persecutions was undertaken by Anglicans - members of a church with virtually no adherents in the Soviet Union. A Christian Protest Committee (CPC) was founded in London at the end of 1929 by the Reverend Alfred William Gough (1862-1931), who also was a member of a fascist group, the National Citizens' Union. ${ }^{23}$ But the $\mathrm{CPC}$ was more a reaction against the restoration of diplomatic relations with the Soviets than an effort to relieve Russian Christians: the Conservative government of Stanley Baldwin had broken off relations with the USSR after the Arcos Raid of May 1927, but with the election of a Labour government under Ramsay MacDonald diplomatic relations had been resumed in October 1929. However, despite its attempts to attract public attention around the issue, the CPC failed to secure the support of the Archbishop of Canterbury, who was mistrustful of this movement, anchored as it was in the radical right.

This initiative was duly relayed to the continent through the mediation of the EIA. With its affiliated groups and correspondents throughout Europe, the organisation systematically scrutinised Soviet newspapers and periodicals, from which it translated extracts and summaries for its Bulletins d'informations. But the EIA strove in vain to extend the CPC's initiative through protests in France and Switzerland. There were three protest meetings in Paris and in Alsace, but they were given the cold shoulder by the press and Catholic leaders alike - the meetings in France being the progeny of a strange coalition between elements of Protestant and emigré Russian Orthodox hue. In Switzerland the campaign stumbled against the fact that the country had no diplomatic relations with the USSR, and was also hindered alse by the incredulity, and perhaps insensitivity, of public opinion. The EIA's lack of professionalism and imagination also put it at a disadvantage: the two major newspapers of French-speaking Switzerland, the Journal de Genève and Gazette de Lausanne, soon tired of the overly long and repetitive communiqués that it sent them almost daily. ${ }^{24}$

Even as anti-religious measures in the USSR were gathering steam, one important actor, the Vatican, had yet to voice a protest. The Holy See had closely watched the progress of the communist regime since 1917 and had welcomed the proclamation of the separation of church and state, as this finally put an end to the overwhelming dominance of the Orthodox Church and allowed hopes of the unfettered development of Catholicism, and the possible return to Rome of the Orthodoxy.25 Roman Catholics represented a substantial minority of the Soviet population, with over fifteen million ethnically heterogeneous believers, mainly Poles, Lithuanians and Germans who followed the Latin rite, and a minority of Russians and Ukrainians who followed the oriental rite. ${ }^{26}$ Though much debated, the promotion of the oriental rite had many supporters in the Vatican, as it was seen as a concrete means of contributing to the conversion of Russia. ${ }^{27}$ Throughout the 1920s, the Vatican had vainly sought a concordat with the Soviet Union, and it had created important institutions under Jesuit leadership - the Oriental Pontifical Institute, the Pro Russia commission and the Collegium Russicum - that were dedicated to the study of Russia. Hopeful of a possible conversion of Russia, and fearful of reprisals against the country's Catholics, Pius XI had been wary of openly criticising the regime. Probably because of this context of competition between Roman Catholicism and Russian Orthodoxy, the Vatican did not at first perceive the fate of the Orthodox Church as genuine martyrdom. ${ }^{28}$ What pushed the Vatican to break its silence was the distressing news it received from the end of 1929 from Father Pie Neveu, the apostolic administrator in Russia, in particular with regard to the arrest of numerous Catholic prelates. ${ }^{29}$ On 2 February 1930, the pope protested against these persecutions in a letter to the cardinal vicar of Rome, Basilio Pompili, which was published in the Osservatore Romano, the official journal of the Vatican.

This initiative was echoed throughout the Catholic press in Europe, and served to prod not only Catholics but also other churches into 
action. In a striking example of this turnaround, the Archbishop of Canterbury received the unanimous support of the Episcopal Assembly for the protest motion he proposed on the 12 February 1930. In an extensive dossier from 19 April 1930, the francophone bi-monthly La Documentation catholique had provided an account of the scope of this European movement, which had contributed to a relative respite in the persecutions: Stalin was concerned about the international image of the regime, as well as about internal peasant unrest. In his famous article 'Dizzy with success', which appeared in Pravda on 2 March 1930, he criticised the excesses of collectivisation and was ironic about some particularly unpopular anti-religious measures. The respite was nevertheless only temporary and the persecution continued. ${ }^{30}$

The shaping of public opinion was only one aspect of the work of west European anti-Bolshevik activists. Another was the organisation of charitable relief actions, though these were dependent on Soviet government approval, and after Moscow had put an end to the papal relief mission for victims of famine and civil war in Russia in 1924, such actions appeared to be the prerogative of Protestants. ${ }^{31}$ One might first of all mention in this connection the Riga-based Baltische Russlandarbeit (Action for Baltic Russia), founded by the German-Latvian pastor Oskar Schabert in $1922 .{ }^{32}$ As well as a periodical, the Russische evangelische Pressedienst (Russian Evangelical Press Service), this organisation distributed brochures on mainly Protestant martyrs, and reproduced the letters it received in great numbers. ${ }^{33}$ Prior to the revolution, there had been fewer than five million Protestants in the Russian empire, and by 1929, according to the press service, there remained only some eighty Protestant pastors, and these were threatened with the same fate that had already befallen four of their imprisoned colleagues. ${ }^{34}$ Based as it was on his intimate respect for Orthodoxy and on a personal experience of the world of Russian prisons - he had been exiled to Siberia in 1915-17 and imprisoned by the Bolsheviks in 1919 - Schabert's action was intended not only to denounce, but also to propose concrete aid on a politically and confessionally neutral basis. The proximity of Riga to the Soviet border also facilitated the collection of information and sending of assistance in the form of money and parcels.

Another charity action was carried out by two support groups for the
Mennonites of German origin who had been installed in the region of the Volga and Ukraine since the end of the eighteenth century. The first was composed of 'Eastern' (Ostforschung) specialists grouped around the magazine Osteuropa run by Otto Hoetzsch in Breslau, and the second was a project of the Protestant Inner Mission, the Eckart publishing house in Berlin. These organisations from Latvia and Germany gathered the earliest first-hand accounts of the terrible persecutions taking place and were a particularly dependable and appreciated source of information for the EIA.

\section{Famine and persecutions}

Though unrelated to the atheist policy of the regime, the tragic episode of the great Ukrainian famine of 1932-3 relaunched the theme of religious persecutions. ${ }^{35}$ It tarnished the image of the USSR and interfered with Moscow's efforts to stabilise its diplomatic relations. Articles in the western press denounced the famine, as did Protestant, Catholic and inter-confessional protests in support of the starving, thereby updating the religious thematic that had somewhat faded from memory since the media coverage of 1930 . The association together of these two phenomena, famine and religious persecutions, allowed propaganda agencies like the EIA to draw attention to flaws in the Soviet regime - though without a great deal of practical success, for in November 1933 the USA officially recognised the USSR. Following this important step, the USSR was subject to a further outcry, but this failed to prevent the final act in the normalisation of its diplomatic situation in September 1934: its admission to a permanent seat on the council of the League of Nations.

Unlike Schabert's efforts, Protestant aid to the hungry from the German organisations was more or less limited to 'settlers' and did not escape appropriation for political ends. A German born in Saratov and active in the Mennonite cause, Adolf Ehrt (1902-75) was in charge of the information section of the German Evangelical Press Service in Berlin, and organiser of the Brüder in Not (Brothers in Distress) action group. He collaborated with the German consul in Kiev, Andor Hencke, who despite the lukewarm response of the German foreign ministry, tried to provide material aid, accorded first and foremost to German immigrants. ${ }^{36}$ In 1933, the work of Brüder in Not was publicised in two 
brochures produced through the Eckart publishing house. ${ }^{37}$ However, the action was politically compromised. Adolf Ehrt had in fact been a member of the Nazi party since 1931 and was president of the Antikomintern, a propaganda organisation financed by the Nazi regime that would not hesitate to make instrumental use of the witness accounts of the 'repatriated' from the Volga and Ukraine.

The activities of Brüder in Not were banned in the USSR in the autumn of 1934, while Schabert's mission continued from Riga. The success of the Baltische Russlandarbeit was nevertheless affected, and a number of clergy were arrested on the grounds of receiving packets from abroad. The Holy See for its part decided against any official relief mission, anticipating a brutal rebuff from the Soviet government and possible negative consequences for Catholics in Russia. ${ }^{38}$ The pope ordered that any offer of help be directed instead to Cardinal Innitzer, who had in the middle of 1933 created an inter-confessional aid committee for starving Ukrainians in Austria. The committee's brochure Hungersnot. Authentische Dokumente über das Massensterben in der Sowjetunion, published in 1934, was one of the first of its type, and was based on the documents and testimonies of survivors, journalists, and diplomats. Its chief spokesperson Ewald Ammende, a German-Baltic Lutheran, was a genuine expert on the Ukraine, and founder and leader of two unimpeachable organisations: Hilfaktion für Petersburg (Aid Action for Petersburg, created in Riga in 1920) and The Congress of European Nationalities, an organ of the League of Nations which since 1925 had reflected upon the fate of minorities in Europe. In 1935 Ammende also published his Muss Russland hungern? Menschen- und Völkerschicksale in der Sowjetunion, based on the photographs of an Austrian engineer who had worked in Russia until 1933. Such credentials, however, counted for little. Despite its balanced and rigorously documented work, Innitzer's committee was immediately discredited by the Moscow press as an anti-Soviet enterprise. ${ }^{39}$

\section{The Pro Deo commission and its exhibition on the Godless}

The EIA, which is rightly characterised as anti-Soviet and had never considered charity as an option, was aware of the difficulty of winning support on religious grounds. It was to this end that it had created the 'Pro Deo' commission as an ostensibly independent inter-denominational organisation. In his memoirs, Georges Lodygensky claimed the initiative had been born of the protests of 1929 and the development of anti-religious propaganda in the west. ${ }^{40}$ The chronology speaks against such a genesis, however, as Pro Deo was founded in October 1933, almost four years after the protests, and at a time when the free-thought movement at an international level had started to decline irrevocably. Pro Deo appeared to be as much a reaction to the victory of the socialists in Swiss cantonal elections as an attempt to prevent the diplomatic advances of the USSR. In the eyes of the EIA leaders there was a threat that Geneva, having now become 'red', would be transformed into a hub for international communism should the USSR be admitted to the League of Nations.

Pro Deo relied on the networks of the Entente to promote a united Christian front against communism. In this Protestants and Catholics, clergy and laity, played a roughly equal role; members of the Orthodox church a distinctly lesser one. The regular members were not mainstream representatives of their denominations, but were drawn from the most radical fringes, and were advocates of a paternalistic vision of society ruled by values of order and authority. The Catholics, even those few Jesuits and Dominicans who attended some Pro Deo conferences, were not entitled to speak in the name of the hierarchy, as laid down in the encyclical letter of 1928, Mortalium animos. Lodygensky, the commission's mainspring, was a follower of the Karlovtsy Synod, a fraction of the divided Orthodoxy in exile, and named after the Yugoslavian town from which it was led. Indeed, the Russian émigrés had just experienced two successive religious shocks: first the rupture in 1927 between the Karlovtsians and the patriarchal church, which was represented in Paris by Metropolitan Euloge and constituted the majority in western Europe; and secondly the rupture in 1931 between Euloge and the Moscow patriarch locum tenens Sergei. ${ }^{41}$ Members of the Synodal Church were essentially ex-officers and soldiers of the White army who had emigrated to the Balkans, and this fraction was known for its monarchist, antisemitic and anti-Catholic tendencies, Lodygensky being an exception in this last respect alone. 
Pro Deo offered the persecuted purely symbolic aid via press campaigns, boisterous speeches and letters to the League of Nations. Its first initiative was a travelling exhibition against 'the Godless'. From January 1934 to May 1935, this covered nineteen towns and cities in Switzerland. Relying on the process of conflation already described, its depiction of the starving in text and image merged with that of those persecuted for their faith. However, Pro Deo did not make the mistake - common at the time - of presenting photographs of the famine of 1921-2 to get around the lack of such images from 1933; rather, it reproduced rare photographs from Brüder in Not, some of which had been taken clandestinely by the wife of the German consul in Kiev. ${ }^{42}$ If the catalogue sounds like a bestseller (65,000 copies) and the organisers claimed an astronomic number of visitors (over 82,000), the actual statistics for the exhibition were rather less impressive. The recipe - banners and reproductions pinned up in haste on makeshift boards, or even on the wallpaper of an apartment rented out for the occasion; a defensive tone; and a curious combination of religious, economic and political arguments - not only failed to produce the desired results; it also gave rise to polemics that damaged the image of Pro Deo. Thus the socialists in Geneva and the French Revue du christianisme social criticised the commission for its use of religious pretexts, while the staging of the exhibition in France, Britain, Yugoslavia and Ireland was to prove an even less resounding success.

\section{The continuous campaign of the Catholic Church}

Little by little, the accent shifted from the martyrs to their executioners. EIA and Pro Deo members activated the thematic of the Godless at opportune moments, while the Catholic Church, for its part, led a continuous campaign against communism and atheism until 1937.43 Launched by the pope in 1932, this campaign followed its own course, without adapting its strategy in any way in order to take account of either previous results or developments within atheist circles. As already noted, the 'Godless' movement was in fact progressively losing intensity by this time, especially outside of the USSR. In 1932 and 1933, fatal blows were delivered to the communist and then the socialist wings of free-thought in Germany and Austria. In 1934, anti-religion moved to the background of the Soviet regime's foreign policy in favour of a rapprochement with the western democracies. In the USSR, the number of believers had not sunk as the regime had hoped: the results of the official 1937 census were so disappointing, especially under the chapter of religion, that they were suppressed. Indeed senior state employees and political leaders responsible for the census were fired or even executed, and another census was ordered for January 1939, from which all questions on religion were carefully removed. ${ }^{44}$

Catholic efforts assumed almost exclusively the written form and mobilised the Jesuits in particular, under the lead of the Superior General of the Society of Jesus in Rome, Father Wlodimir Ledóchowski. This Polish priest of Austrian citizenship was a fervent anti-communist, and he assigned the society's priests to the struggle in each country. At the beginning of 1936, the efforts of his informal camarilla, which was not representative of all Jesuits, resulted in the publication of an indigestible 'Catholic Summa against the Godless' (Essai d'une Somme catholique contre les sans-Dieu). Meanwhile, in March 1936, the pope ordered a confidential 'crusade of prayer' for Christians persecuted in the USSR and ... for the conversion of Russia.

A competition for an anti-Bolshevik novel, launched by the Catholic Institute in Paris at the (secret) instigation of Pius XI in 1932, was intended to promote a more digestible literature that might leave its mark on the general public. ${ }^{45}$ Though richly endowed, however, the competition was sluggish: writers of repute refrained from entering, and the numerous manuscripts that reached the jury from around the world were of very poor quality. The announcement of the results had to be put back, and it was not until 1936 that they were finally made public. The winning novel, Die Fabrik der neuen Menschen (The New Men Factory), depicts a system where depravity and cruelty towards believers are generalised. The plot takes place in a GPU work commune - the factory of the title - and tells the unsettling, almost sadistic, love story of a pious young woman (Tania) and a brutal, godless Tovaritch (Vladimirov), who becomes a believer at the end of the novel. The message is that the martyrdom of Tania was worth going through, as it ended up with Vladimirov's conversion. The author, Alia Rachmanova, was a Russian 
emigrée who had converted to Catholicism. This highly revealing choice exacerbated the discontent among Orthodox emigrés, who were already incensed by a competition that seemed to deny any value in their own abundant literary production on the subject. One might also add that, in the light of the growing importance of the cinema, such a competition for edifying novels was arguably looking to the past rather than the future.

With the outbreak of the Spanish Civil War, Christian anti-communists did not miss the opportunity it afforded to once more seize on the thematic of religious persecutions. But the conflict served to cause some cracks to open up in the Catholic world, especially among French Catholic intellectuals, who at one time had been so homogenous in respect of 'Godless' regimes. ${ }^{46}$

On 19 March 1937, the publication of Divini Redemptoris marked the climax in a growing denunciation of Soviet atheism by the pope. ${ }^{47}$ The encyclical that had been published five days previously, Mit brennender Sorge - which dealt with the treatment that the Third Reich reserved for the German Catholic Church - could not compete with its anti-communist sibling, whose distribution was much larger, tone much sharper, and verdict more definitive. ${ }^{48}$ This imbalance was also reflected in the positions of the anti-communist organisations. Under diverse pretexts and justifications, Pro Deo and the majority of its correspondents refused to denounce the serious religious problems in Germany. A major reason for this was the German section affiliated to Pro Deo that in reality was a cover for the Nazi Antikomintern office, with which the EIA and Pro Deo had been collaborating, and from which Lodygensky drew monthly subsidies. With its silence regarding Nazi persecutions, Pro Deo implictly disavowed the political neutrality it had once proclaimed. Unsurprisingly, the commission did not judge it necessary to protest against the persecution of the Jews.

\section{A new martyr factory?}

The prevailing martyr figure in the 1930s denunciations was a dolorific one, in which sacrifice for the sake of faith was praised as a virtue. Anticommunist propaganda took up this trend, circulating photographs of anonymous wandering beggar priests and devastated places of worship. Here some striking continuities may be observed in the period after the Second World War, when persecutions against religion resumed, and expanded to the new communist countries in different shades of grey. Firstly, the Vatican continued as a major player and valued ally, though steadfastly following its own path, which it refused to subordinate to others' conceptions - be they Truman's or Reagan's.49 In spite of this, however, and with strong American support, after 1947 the propaganda for the 'Free World', and in favour of the underground dissidence of the major Christian churches behind the Iron Curtain - referred to as the 'Church of silence' - appears to have been more successful than previous efforts. Secondly, the persisting religious reference to martyrs was no less significant than it had been in the inter-war era..$^{50}$ Denunciation and charitable initiatives blossomed between the 1950s and the 1970s (inviting further investigation). Most of the martyrs of the Church of silence were, for obvious reasons, anonymous, but there were some Catholic hero martyrs, such as the 'cardinals in captivity', József Mindszenty in Hungary, Stefan Wyszyński in Poland, and Alojzije Stepinac in Yugoslavia. ${ }^{51}$

After 1989, some lamented the 'eclipsing' of the Christian martyrs, and the fading of their significance in the memory.52 This trend was stronger at the heart of Catholicism, the propensity for celebrating martyrs appears to have been reinforced by the imperatives of the 'duty of remembrance' and the struggle against forgetting. In contemplation of the jubilee in 2000, Pope John Paul II launched a 'quest of remembrance for the Christians that fell in the 20th Century'. ${ }^{53}$ Without denying the specificities of the Shoah - that other story of martyrdom of unprecedented dimensions and nature - recent Catholic historiography has reclaimed the status of the 'Church of Martyrs' for the Catholic church of the past century, and tried to give voice to the 'witnesses to the faith'. In what Annette Wieviorka has referred to as the 'era of the witness' that we have entered, everyone claims their place - especially since the Cold War, and some of the regimes that survived it, produced and continue to produce their own share of persecuted Christians. ${ }^{54}$ The Vatican's 'New Martyrs' Commission documented more than twelve thousand life stories in two years of active collecting. Pope John Paul II was doubtless 
not aware that he was opening a Pandora's box that might, in some cases, serve a purpose other than historic truth or pastoral revival. The rising of passions and the ensuing flood of beatification procedures that occurred under his successor, took place in circumstances that were very different politically, now that the former USSR was no longer the epicentre. Other embers were rekindled, particularly in Spain. Benedict XVI's decision, in 2007, to proceed with the mass beatification of 498 Spanish clergy killed in the Republican zone during the Spanish Civil War raised lively controversies. ${ }^{55}$ Overlooking the thirteen or so Basque priests assassinated by Franco's supporters, whose names were 'forgotten' on the list, the initiative could not fail to attract debate.

Traditionally, Protestantism - which does not recognise 'saintly communion' - has not had to confront this phenomenon with the same intensity. It has not entirely escaped the commotion of remembrance, but historian of Christianity Gottfried Hammann has written - not without regret - that in contemporary historiography, Protestant martyrology has 'dissipated into indifference'. ${ }^{56}$ As he remarked, the imposing figure of pastor Dietrich Bonhoeffer seems to cast all the other martyrs of the twentieth century into the shade. However, some voluminous publications have recently seen the light of day which seem to echo the Catholic impulsion - again, in a dynamic not entirely dissimilar to that of the 1930 s. ${ }^{57}$

Beyond these continuities, evolutions can also be observed. The reference to the 'East' has expanded to other areas than the late Soviet bloc. These include not only wider geographical areas where Christians are minorities in a hostile political and religious context, such as China, Egypt and Pakistan, but also what might be thought of as inner, domestic 'Easts' threatening 'Christian Civilisation'. Examples here might include Muslim immigration, the secular state and school, and legislation on abortion, gay marriage and adoption. Such are the concerns of new Catholic defence movements. A few months apart in 2013 two 'Christianophobia Observatory' organisations were created. The Italian branch originates from the association Luci sull'Est (Lights on the East), created in Rome in 1991, and is devoted to the promotion of the Marian cult of Fatima, which is linked to the fight against communism, and to the defence of catholic family values and private property. The French branch was first launched as a blog linked to the 'catholic portal of reinformation' Riposte catholique (Catholic reprisal), and was spurred by the debate on equal marriage rights that has been raging in that country. Both these defence groups tend to present all French (or Italian) Christians as potential martyrs.

There are other examples of hotbeds threatening to ignite, in particular against Islam. These call for the vigilance of the historian community, and for advances in inter-religious dialogue, in order to counter attempts to instrumentalise martyrs in unresolved conflicts of remembrance, and the spectre of a new culture war.

The account presented here draws on the author's doctoral research, subsequently published as Stéphanie Roulin, Un credo anticommuniste. La commission Pro Deo de l'Entente internationale anticommuniste ou la dimension religieuse d'un combat politique (1924-1945), Lausanne: Antipodes, 2010. She is greatly indebted to Todd Weir for his inspiring suggestions, especially on the interpretation of the culture war as a wider historical phenomenon, which he develops in ongoing research. She would also like to express her gratitude to Dianne Kirby for her invaluable commentaries. Of course, the author is responsible for all deficiencies of the text.

\section{Notes}

1. Numerous studies could be cited here, from the pioneer collected essays edited by Dianne Kirby, Religion and the Cold War, Basingstoke: Palgrave Macmillan, 2003, to the more recent Philip E. Muehlenbeck (ed.), Religion and the Cold War: A Global Perspective, Nashville: Vanderbilt University Press, 2012, and the forthcoming Johannes Grossmann, Die Internationale der Konservativen. Transnationale Elitenzirkel und private Außenpolitik in Westeuropa seit 1945, Munich: Oldenbourg, 2014.

2. The intellectual and liberal tendencies in all three denominations discussed, including the émigré orthodox intelligentsia around personalities like the distinguished theologian Nicolas Berdiaev, are left to one side.

3. See Michel Caillat, 'Théodore Aubert and the Entente internationale anticommuniste: an unofficial anti-marxist international', Twentieth Century Communism, 6, 2014. 
4. Aubert to the Revd. Dr S Parkes Cadman, New York, and other religious personalities, 19 February 1930. EIA archives, Library of Geneva (hereafter EIA), Etats-Unis 1930-1.

5. See Jean Meyer, La révolution mexicaine, 1910-1940, Paris: CalmannLévy, 1973; and Apocalypse et révolution au Mexique. La guerre des Cristeros (1926-1929), Paris: Gallimard/Julliard, 1974; Matthew Butler (ed.), Faith and Impiety in Revolutionary Mexico, New York: Palgrave Macmillan, 2007.

6. Roulin, Un credo anticommuniste.

7. Gottfried Hammann, 'Sainteté et martyre selon la tradition protestante', Pierre Centlivres (ed.), Saints, sainteté et martyre. La fabrication de l'exemplarité, Neuchâtel/Paris: Institut d'ethnologie de Neuchâtel/ Maison des sciences de l'Homme, 2001, pp27-67.

8. See Lukas Vischer, Lukas Schenker, Rudolf Dellsperger and Olivier Fatio (eds), Histoire du christianisme en Suisse, Geneva: Labor et Fides, 1995, pp249-50; Victor Conzemius (ed.), Schweizer katholizismus 1933-1945, Zurich: NZZ, 2001.

9. William B. Husband, Godless communists. Atheism and Society in Soviet Russia, 1917-1932, DeKalb: Illinois University Press, 2000, p35.

10. See the state of the art by Arto Luukkanen, The Party of Unbelief. The Religious Policy of the Bolshevik Party 1917-1929, Helsinki: SHS, 1994, pp26-32. See also Pospielovsky's History of Atheism in Theory and Practice, and the Believer, London: Macmillan, 1987-1988 (in three volumes), which still remains an indispensable reference, as well as more recent studies that could benefit from the opening of the Soviet archives, such as Daniel Peris, Storming the Heavens: The Soviet League of the Militant Godless, Ithaca, NY: Cornell University Press, 1998; and Husband, Godless communists.

11. S.M. Miner, Stalin's Holy War: Religion, Nationalism, and Alliance Politics, 1941-1945, Chapel Hill: University of North Carolina Press, 2003.

12. Pospielovsky, II, p19.

13. Husband, Godless communists, pp54, 72; Pospielovsky, I, pp27-29.

14. Catherine Gousseff, 'Le schisme rénovateur: un mouvement pro-communiste dans l'Église orthodoxe russe', Revue d'Études comparatives Est-Ouest, 1993, 3-4, pp9-28
15. Husband, Godless communists, p59.

16. Nicolas Werth, 'Le pouvoir soviétique et l'Eglise orthodoxe de la collectivisation à la Constitution de 1936', Revue d'études comparatives Est-Ouest, №3-4, septembre-décembre 1993, pp41-49.

17. Husband, Godless communists, p88.

18. Werth, 1993.

19. Husband, Godless communists, pp130-158.

20. Nicolas Werth, “'Cher Kaliniouchka ...”. Lettres paysannes à Kalinine, 1930', in La terreur et le désarroi. Staline et son système, Paris: Perrin, 2007, p86-100.

21. Pospielovsky, I, pp33, 157 n13.

22. Pospielovsky, I, pp84-6.

23. On the National Citizen's Union, see Markku Ruotsila, 'The Antisemitism of the Eighth Duke of Northumberland's the "Patriot", 1922-1930', Journal of Contemporary History, 39, 1, 2004, pp71-92.

24. EIA activity report (untitled document; $1^{\text {st }}$ trimester, 1930). EIA, box 'Bureau permanent 1924-1930'.

25. Of the important literature on the Holy See and the USSR, see in particular the detailed study (and the bibliography therein) by Laura Pettinaroli, 'La politique russe du Saint-Siège (1905-1939)', PhD thesis, Lyon 2, 2008, online http://theses.univ-lyon2.fr/ (accessed 26 September 2013).

26. Andrea Riccardi, Ils sont morts pour leur foi. La persécution des chrétiens au $X X^{e}$ siècle, Paris: Plon/Mame, 2002, pp23-55. See the population statistics by religion according to the last census under the tsarist regime, in 1897, as reported by Pettinaroli, 'La politique russe', p99.

27. Pettinaroli, 'La politique russe', p846.

28. Pettinaroli, 'La politique russe', p671.

29. The silence was relative, as the pope had already made allusion to the Soviets' 'works of impiety' in consistorial addresses, as well as in the encyclical regarding the education of the youth, Divini illius magistri, of 31 December 1929 and other texts.

30. Pospielovsky, II, p64.

31. The action of Catholic authorities such as the German Caritas-Verband, as well as support groups from Lvov (then in Polish territory) evoked by Dmytri Zlepko in 'Alles ist wunderbar', Osteuropa, 12, 2004, pp192-203, 
may not perhaps be quite so isolated as it appears and would be worthy of research.

32. Christian Weise 'Oskar Schabert', Biographisch-bibliographisches Kirchenlexikon, Vol. XX (2002), pp1264-1270: www.bautz.de/bbkl/s/s1/ schabert_o_a_k.shtml, accessed 26.09.13.

33. Notably, Baltisches Märtyrerbuch, Berlin: 1926; Märtyrerbilder aus Russland, Riga: 1935.

34. Letter from Oskar Schabert to Théodore Aubert, 15 January 1930, EIA, Lithuania, Latvia, Norway, Japan 1930.

35. On this famine, which has been submitted to various divergent interpretations, we refer to the balanced overview by Nicolas Werth, La terreur et le désarroi. Staline et son système, Paris: Perrin, 2007.

36. Zlepko in 'Alles ist wunderbar'.

37. Brüder in Not and Hungerpredigt, Deutsche Notbriefe aus der Sowjetunion (The preachings of famine, German Letters of Distress from the USSR).

38. Pettinaroli, 'La politique russe', p585.

39. Zlepko in 'Alles ist wunderbar'.

40. Georges Lodygensky, ed. Youri Lodygensky and Michel Caillat, Face au communisme (1905-1950). Quand Genève était le centre du mouvement anticommuniste mondial, Geneva: Slatkine, 2009.

41. Catherine Gousseff, 'Une intelligentsia chrétienne en exil: les orthodoxes russes dans la France des années 1920', in Intellectuels chrétiens et esprit des années 1920, Paris: Colin, 1997, p129.

42. Etienne Thevenin, 'France, Allemagne et Autriche face à la famine de 1932-1933 en Ukraine', James Mace Memorial Panel (29.06.2005): www.garethjones.org/ukraine2005/Etienne\%20Thevenin.pdf (accessed 26.09.13)

43. For a synthesis on the position of the Catholic Church towards communism, see Philippe Chenaux, L'Eglise catholique et le communisme en Europe (1917-1989), Paris: Cerf, 2009.

44. Alain Blum, Naître, vivre et mourir en URSS, Paris: Payot, 2004 edn, pp42-5.

45. Stéphanie Roulin, 'Le concours international de romans antibolcheviques, ou comment faire de la "bonne littérature" médiocre (1933-1936)', in Claude Hauser et al (eds), La diplomatie par le livre (1880-1980), Paris: Nouveau Monde, 2011
46. See the controversy surrounding the French writers Georges Bernanos, François Mauriac, and the philosopher Jacques Maritain. Michel Winock, 1997, Le siècle des intellecuels, Paris, Seuil.

47. Etienne Fouilloux, Les catholiques et l'unité chrétienne du XIX au XX siècle. Itinéraires européens d'expression française, Paris: Centurion, 1982, p384.

48. Etienne Fouilloux, 'Le Vatican entre Hitler et Staline', in L'Histoire, 70, 1984, pp34-42.

49. See the contributions by Peter C. Kent, Tony Shaw and Dianne Kirby in the volume edited by the latter: Religion and the Cold War, Basingstoke: Palgrave Macmillan, 2003; and Marie Gayte, 'Les Etats-Unis et le Vatican dans les années 1980. Au-delà de la "sainte alliance", Vingtième siècle, 111, 3, 2011, pp105-17.

50. The reference to martyrdom is implicit in a title such as Catacombes (Supra Denominational Messenger of the Church of Silence), a periodical first issued in 1971 in Paris by a Rumanian emigré, Serge Grossu.

51. See Shaw in Religion and the Cold War, p220.

52. E.g. the French historian Alain Besançon, an ex-communist who has shifted towards catholic integralism, cited in Chenaux, L'Eglise catholique et le communisme, p24, or the Swiss theologian and historian of the Church Gottfried Hammann, 'Sainteté et martyre'.

53. Andrea Riccardi, Ils sont morts pour leur foi: la persécution des chrétiens au $X X^{e}$ siècle, Paris: Plon/Mame, 2002, p7.

54. From the book by Annette Wieviorka, L'ère du témoin, Paris: Plon, 1998.

55. Mari Carmen Rodríguez; François Godicheau, 'Les "abus de la mémoire" au Vatican', online at the website of the Comite de vigilance face aux usages publics de l'histoire, 2007: http://cvuh.blogspot.ch/2007/11/lesabus-de-la-memoire-au-vatican-par.html (accessed 26 September 2013).

56. Hammann 2001.

57. In particular, we would like to mention the annual publication Märtyrer: das Jahrbuch zur Christenverfolgung heute, as well as the annual 'World watch list' (Christian persecution rankings) of the NGO Open Doors: www.opendoors.org/ (accessed 26 September 2013) 